\title{
OPTIMUM REPLACEMENT LEVEL OF THE SOYBEAN MEAL FOR PROCESSED HORSE EYE BEAN MEAL (MUCUNA URENS) IN THE BROILER FINISHER DIET.
}

\author{
O. O. EFFIONG, M. E. WILLIAMS, L. N. AGWUNOBI AND I. P. AKPAN
}

(Received 28, September 2011; Revision Accepted 1, November 2011)

\begin{abstract}
The high cost of broiler production in Nigeria has been attributed to overdependence on the most expensive conventional protein sources. Hence the need to source for alternative but promising feedstuffs. A 28- day feeding trial was therefore conducted to determine the feeding processed horse eye bean meal (HEBM) in finisher broiler ration. Six experimental diets were formulated. Diet 1 was the control, while various quantities of HEBM was used to replace soy bean meal (SBM) in the control diet at $15,30,45,60$ and $75 \%$ for diets $2,3,4,5$, and 6 , respectively. Two hundred and sixteen, 28 days old broilers used for the experiment were distributed on weight equalization basis into three replicates of 36 birds per treatment in a completely randomized design. Data generated were statistically analysed and the significant means separated. The result showed that increased level of HEBM in the diet did not significantly $(P>0.05)$ influence the final body weight, average weekly weight gain, average weekly feed intake and the feed conversion ratio. Equally, the weight of cut parts and internal organs were not statistically $(P>0.05)$ affected. The cost $/ \mathrm{kg}$ of feed, cost of feed consumed and cost $/ \mathrm{kg}$ weight gain reduced significantly $(P<0.05)$ with increase in the level of HEBM in the diet. It was concluded that up to $60 \%$ of the SBM in the broilers finisher diet could be replaced by processed HEBM for higher economics returns.
\end{abstract}

KEY WORDS: Processed Horse Eye Bean, Anti-Nutritional Factors, Soaking, Cooking, Broiler Finisher Diet.

\section{INTRODUCTION}

The protein intake of Nigerians has been on a decline as a result of ever increasing population. The level of animal protein consumption has direct influence on the general well being and health of populace (Bamigbose et al., 2002). Poultry production, especially the broiler chicken offers a considerable potential to bridge the animal protein intake gap for the fact that poultry with the help of incubator has the highest fecundity among farm animals. It grows faster, mature earlier, has greater affordability, easy to raise, absence of taboos to production and consumption than other species of livestock (Akinmutimi and Okwu, 2006; Mudubuike and Obidimma, 2009).

Feed cost alone in poultry enterprise is about 70 $\%$ of the total cost of production (Ogunfowora, 1984), which has been attributed to overdependence on the conventional feedstuffs such as soybean and groundnut cake (Ani 2008). A high demand for these feed ingredients has resulted in an increase in their prices and consequently cost of poultry feed and its products (Akinmutimi et al. 2002). Hence the need to source for alternative but promising feedstuffs. One of them is the horse eye bean meal (Osaniyi and Eka, 1978), which is widely available and thrive well even at extremely climatic conditions. The bean yields about 3-5 tons of seeds per hectare, with the crude protein and carbohydrate contents of 24 and 56\% (Umoren et al., 2007).

Horse eye bean (Mucuna urens) contain antinutritional factors (tannins, phytates, hydrogen cyanides, L-Dopa, non-starch polysaccharides etc) which limit its utilization. Osaniyi and Eka, (1978) reported 100\% mortality of broiler birds fed diet containing raw horse eye bean meal (HEBM) within three days, while Umoren et al., (2007), reported poor performance of rats fed diet containing cooked, autoclaved, germinated or toasted HEBM.

Effiong, (2010) noted that combining soaking for 48 hours, cooking for 90 minutes and toasting at $100^{\circ} \mathrm{C}$ as processing method significantly improved the quality of the horse eye bean meal. It is against this back drop that this study was embarked upon to determine the optimum replacement level of the 48 hours soaked, 90 minutes cooked and toasted horse eye bean meal for soybean meal in the broiler finisher ration.

O. O. Effiong, Department of Animal Science, University of Calabar, Nigeria

M. E. Williams, Department of Animal Science, Akwa Ibom State University, Nigeria

L. N. Agwunobi, Department of Animal Science, University of Calabar, Nigeria

I. P. Akpan, Department of Animal Science, University of Uyo, Nigeria 


\section{MATERIALS AND METHODS}

Study location and source of the experimental material: The experiment was conducted at the teaching and research farm unit of the Department of Animal Science, University of Calabar, Nigeria, between November and December, 2009. The experimental site is located between Latitude $04.57^{\circ} \mathrm{N}$ and Longitude $08.20^{\circ} \mathrm{E}$. The horse eye beans meal used for the study was purchased from the local farmers in Akamkpa Local Government Area of Cross River State.

\section{Processing of the horse eye bean}

The horse eye beans used for this study were cracked using stone, soaked in fresh clean water for 48 hours at room temperature $\left(37^{\circ} \mathrm{C}\right)$, peeled, rinsed in fresh water, cooked for 90 minutes on open fire at $100^{\circ} \mathrm{C}$ (timing started from the point of boiling), rinsed in clean water and sun-dried. The dried beans were toasted in frying pot, on open fire until they turned brown at 30 minutes, approximately. The processed beans were milled on $4 \mathrm{~mm}$ screened hammer mill and used for feed formulation.

\section{Experimental diets}

Six (6) broiler finisher diets were formulated to provide 20 per cent crude protein and the metabolizable energy of about $3,000 \mathrm{kcal} / \mathrm{kg}$. Diet 1 was the control, containing no HEBM, while diets 2 to 6 contained the processed meal, replacing 15, 30, 45, 60 and 75 per cent of soybean meal (SBM) in the respective diets. The Metabolizable energy of the processed horse eye bean meal was calculated from the proximate chemical composition data using formula: $\mathrm{ME} \mathrm{Kcal}{ }^{-1}=37 \times \% \mathrm{CP}$ $+81.8 \times \% \mathrm{EE}+35.5 \times \% \mathrm{NFE}$ (AOAC, 1990). The bean contained $3552.55 \mathrm{Kcal} / \mathrm{Kg}$ of Metabolizable energy.

\section{Experimental birds and design}

Two hundred and sixteen (216), 28 days old broilers were used for this experiment.

The birds were weighed and grouped according to their body weight into six (6) groups of thirty six (36) birds. Within each group, birds were further divided into three (3) sub-groups of 12 birds, so that the overall mean weights and weight ranges were similar across the groups. Groups were randomly allocated to one of six experimental diets in a completely randomized design. Each diet was fed as mash throughout the experiment. Feed and water were provided ad libitum. Feed intake (pen basis) was measured daily; the weights of birds were taken weekly. Both the feed intake and weight gain were used to calculate the feed conversion ratio.

At the end of trial, two (2) birds per replicate ( 6 birds per treatment) were randomly selected, fasted for 18 hours, individually weighed, slaughtered and eviscerated. The weight of different parts and internal organs (heart, kidney, liver, gizzard, proventriculus and intestine) were taken and expressed as percentages of live-weight.

\section{Data analyses}

Data generated from the experiment, were statistically analyzed, using the analyses of variance procedures. Significant means were separated by Duncan's New Multiple Range Test (1995).

Table 1: Composition of experimental diet for broiler chicken during finisher phase.

\begin{tabular}{|c|c|c|c|c|c|c|}
\hline \multirow[b]{2}{*}{ Ingredients } & \multicolumn{5}{|c|}{ Levels of HEBM (\%) } & \multirow[b]{2}{*}{75} \\
\hline & 0 & 15 & 30 & 45 & 60 & \\
\hline Maize & 54.1 & 52.2 & 49.9 & 47.1 & 43.7 & 39.4 \\
\hline Soybean meal & 22.4 & 20.7 & 18.6 & 16.2 & 13.1 & 9.3 \\
\hline Horse eye bean meal & - & 3.6 & 8.0 & 13.2 & 19.7 & 27.8 \\
\hline Fish meal & 3.0 & 3.0 & 3.0 & 3.0 & 3.0 & 3.0 \\
\hline Wheat offal & 8.0 & 8.0 & 8.0 & 8.0 & 8.0 & 8.0 \\
\hline Palm kernel cake & 5.0 & 5.0 & 5.0 & 5.0 & 5.0 & 5.0 \\
\hline Salt & 0.5 & 0.5 & 0.5 & 0.5 & 0.5 & 0.5 \\
\hline Bone meal & 3.0 & 3.0 & 3.0 & 3.0 & 3.0 & 3.0 \\
\hline Lysine & 0.3 & 0.3 & 0.3 & 0.3 & 0.3 & 0.3 \\
\hline Methionine & 0.2 & 0.2 & 0.2 & 0.2 & 0.2 & 0.2 \\
\hline -Vitamin/mineral premix & 0.5 & 0.5 & 0.5 & 0.5 & 0.5 & 0.5 \\
\hline Total & 100 & 100 & 100 & 100 & 100 & 100 \\
\hline \multicolumn{7}{|l|}{ Calculated Analysis } \\
\hline Crude protein (\%) & 20.0 & 20.0 & 20.0 & 20.0 & 20.0 & 20.0 \\
\hline $\mathrm{ME}(\mathrm{Kcal} / \mathrm{kg})$ & 3,000 & 3,000 & 3,000 & 3,000 & 3,000 & 3,000 \\
\hline \multicolumn{7}{|l|}{ Determined analysis } \\
\hline$\%$ Crude protein & 19.98 & 19.95 & 19.97 & 20.12 & 20.05 & 20.20 \\
\hline ME (Kcal/kg) & 3001 & 3,003 & 3001 & 2999 & 3000 & 2996 \\
\hline
\end{tabular}

-Vitamin/mineral premix containing the following per $\mathrm{kg}$. Vitamin A 8,000000 I.U; Vitamin D3 1,600000IU; Vitamin E 5,000IU; Vitamin K 2,000mg; Thiamine 1,500mg; Riboflavin B2 4,000mg; Pyridoxine B6, 1,500mgr; Anti oxidant 125g; Niacin1,500mg; Vitamin B12 10mg; Panthotenic acids 5,000mg; Folic acid 500mg; Biotin 20mg; Choline chloride $200 \mathrm{~g}$, manganese $80 \mathrm{~g}$; Zinc 50g; 1ron 20g; copper 5g; lodine 1.2g; Selenium 200mg; Cobalt $200 \mathrm{mg}$ 


\section{RESULTS AND DISCUSSION}

Data for the performance of the finisher broiler fed on the six experimental diets are shown in Table2. The final weight and the average weekly weight gain of the broiler were significantly $(P<0.05)$ affected with increase in the level of HEBM in the diet. Birds fed diet containing 30 per cent HEBM recorded the highest average weekly body weight gain (258.82g); while birds fed diet containing 75 per cent processed HEBM had the least value $(182.95 \mathrm{~g})$.

The average weekly body weight gain increased significantly $(P<0.05)$ with corresponding increase in the level of HEBM in the diet but decreased at 75 per cent HEBM dietary replacement. The result of this experiment shows that broiler birds can effectively utilize the processed HEBM at the finisher phase. Better utilization of the bean at this phase can be attributed to increase in enzymatic activities, leading to the breakdown of the non starch polysaccharides, as evidenced in the disappearance of the sticky droppings. Effiong, (2010) reported sticky droppings and poor growth rate in broiler chicks fed graded levels of HEBM diet at starter phase.

Values obtained in this experiment were higher than a range (114-171g) reported by lyayi et al. (2005) for broiler birds fed diet containing processed velvet bean meal during finisher phase. The values were however lower than the range (293.79 - 357.49g) reported by Akinmutimi and Okwu (2006) for finisher broilers fed diet containing cooked Mucuna utilis meal, but similar to a range of 190.4 - $245.7 \mathrm{~g}$ reported for finisher birds fed diet containing differently processed Mucuna pruriens (velvet beans).

The lowest average weekly feed intake (520.81g) was recorded on birds fed diet containing 75 per cent processed HEBM, while the highest feed intake of $595.02 \mathrm{~g}$ was recorded in birds fed the control diet. The differences in the average weekly feed intake was however not significant $(P>0.05)$ among the treatment groups. The range observed in this experiment was higher than 370 to $473 \mathrm{~g}$ reported by lyayi et al. (2005), but lower than $(1,010.8-1,164.8 \mathrm{~g})$ reported by Emenalom and Udedibie (2005). Tuleun and Patrick (2007) reported 594.51 - 662.34g as average weekly feed intake for finisher broiler fed diet containing cooked Mucuna utilis seed meal, which is similar to the findings of this experiment.

The feed conversion ratio ranged from 2.78 in birds fed diet containing 75 per cent processed HEBM to 2.06 in bird fed 30 per cent HEBM diet. The values however were not significantly $(P>0.05)$ different among the treatment groups. The result of this experiment shows that birds on 15, 30 and 60 per cent HEBM recorded better (although not significant) FCR values than the control group. This implies that the HEBM diets were effectively utilized. The result of this experiment agrees with the findings of Oluyemi and Robert (2000), Nyirenda et al. (2003), and Tuleun and Patrick (2007). These authors reported $2-2.5,2.01-2.47$ and $2.38-$ 2.52 as the feed conversion ratio of finisher broilers fed mucuna bean based diets. Emenalom and Udedibie (2005), Fanimo et al. (2007) and Emenalom et al. (2009) reported average FCR values of $5.39,2.93$ and 3.43, which are higher than values obtained in this study.

Results of the carcass and internal organs characteristics are shown in Table 3.

Dressing percentage expressed as percentage of the live weight did not show any significant $(P>0.05)$ difference. The mean weight of cut parts as a percentage of live weight was not significantly $(P>0.05)$ influenced by the level of the processed HEBM in the diet. The mean weight of internal organs as percentage live weight followed a similar trend in that there was no significant $(P>0.05)$ difference in all the parameters measured. Increase in gizzard weight among birds may represent greater work of digestion and metabolism by this organ in the processing of the feedstuff (Carew et al., 2003. lyayi et al. (2005) and Adeyemo and Longe (2007) reported $3.61-3.83$ and $3.54-5.18$, respectively as ranges for weights of gizzard fed HEBM based diet. These values agree with the findings of this experiment. Emenalom and Udedibie (2005); Akinmutimi and Okwu (2006) also reported 4.4 - 4.65 and 4.31 5.180 as weight ranges for gizzard in birds. The reports of these authors are higher than values obtained in this experiment. Kidney weights $(0.17-0.25,0.65-0.7$ and 0.79 - 0.92) has been reported by Emenalom and Udedibie (2005), Emiola and Ologhobo (2006) and Akinmutimi and Okwu (2007), respectively.

Liver weight ranged from 1.79 in bird on 45 per cent HEBM diet to 2.76 in birds fed diet with 15 per cent HEBM. However, the average weight of liver obtain in this experiment agrees with those reported by Emiola and Ologhobo (2006), Emenalom et al., (2007) and lyayi et al. (2005). Values for heart weight ranged from 0.57 in birds fed diet containing 15 per cent HEBM to 0.69 in birds fed diet with 45 per cent HEBM. Values for proventriculus ranged from 0.43 in birds fed diet with 45 per cent HEBM to 0.65 in birds fed diet with 15 per cent HEBM. Enlargement of the heart muscle may represent extra work load imposed by stress or disease (Carew et al., 2003). Non significant relationship among treatment groups in these parameters show that the residual ANFs do not have observable effects on the organs.

The economic efficiency of feeding processed HEBM to finisher broilers is presented in Table 4.

The cost/kg feed in Naira, cost of feed consumed by birds in Naira and the cost of $\mathrm{kg} /$ weight gain were reduced significantly $(p<0.05)$ as the inclusion levels of processed HEBM increased from 15 to 75 per cent in the diet. The cost /kilogram of feed reduced from $\mathrm{N}$ 83.12 in $15 \%$ HEBM Diet to $\mathrm{N} 76.42$ in diet containing $75 \%$ HEBM. The least cost per $\mathrm{kg}$ of feed observed for diet with $75 \%$ HEBM is as a result of lower cost of processed HEBM. Cost of feed consumed was reduced

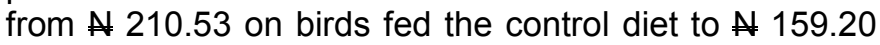
on birds fed $75 \%$ HEBM diet. The reduction in the cost of feed consumed among birds fed HEBM diets has been attributed to decrease in cost $/ \mathrm{kg}$ of feed, due to lower cost of HEBM. The inclusion of HEBM in broiler finisher ration significantly reduced the Cost $/ \mathrm{kg}$ of weight gain relative to the control diet. The Cost $/ \mathrm{kg}$ of weight gain for birds on 75\% HEBM diet was however not statistically different from those on control diet. 
Diet containing 60 per cent processed HEBM seem to be the most economically advantageous as a result of moderate cost per $\mathrm{kg}$ of feed consumed and good live- weight. This cumulatively made the cost per $\mathrm{kg}$ weight recorded in this group lower than others.

Table 2: Performance of broiler chickens fed diets containing graded levels of 48 hours soaked and 90 minutes cooked and toasted horse eye bean (Mucuna urens) meal during finisher phase

\begin{tabular}{|c|c|c|c|c|c|c|c|}
\hline \multirow[t]{2}{*}{ Parameters } & \multicolumn{6}{|c|}{ Levels of HEBM (\%) } & \multirow[b]{2}{*}{75} \\
\hline & $\begin{array}{c}0 \\
\text { SEM }\end{array}$ & 1 & 3 & & 45 & 60 & \\
\hline Initial weight/bird(g) & 358.33 & 3.59 .58 & 360.83 & 362.08 & 358.75 & 361.67 & \pm 0.49 \\
\hline Final weight/bird $(\mathrm{g})$ & $\begin{array}{c}1,308.9 \\
6\end{array}$ & $1,314.75$ & $1,396.11$ & $\begin{array}{c}1,335.7 \\
5\end{array}$ & $\begin{array}{c}1,329.1 \\
6\end{array}$ & $1,093.46$ & \pm 3.98 \\
\hline Weight gain/bird (g) & 950.63 & 955.17 & $1,035.28$ & 973.67 & 970.41 & 731.79 & \pm 2.44 \\
\hline $\begin{array}{l}\text { Average weekly weight } \\
\text { gain/bird }(\mathrm{g})\end{array}$ & 237.66 & 238.79 & 258.82 & 243.30 & 242.60 & 182.95 & \pm 2.03 \\
\hline $\begin{array}{l}\text { Average weekly feed } \\
\text { intake }(\mathrm{g})\end{array}$ & 595.02 & 549.55 & 576.71 & 535.89 & 553.31 & 520.81 & \pm 2.02 \\
\hline Feed conversion ratio & 2.50 & 2.32 & 2.06 & 2.54 & 2.26 & 2.78 & \pm 0.2 \\
\hline
\end{tabular}

SEM- Standard Error of Mean

Table 3: Carcass and internal organs characteristics of broiler chicken fed diets containing graded levels 48 hours soaked 90 minutes cooked and toasted horse eye bean meal (\% live weight).

\begin{tabular}{|c|c|c|c|c|c|c|c|}
\hline \multirow[t]{2}{*}{ Parameters } & \multicolumn{6}{|c|}{ Levels of HEBM (\%) } & \multirow[b]{2}{*}{ SEM } \\
\hline & 0 & 15 & 30 & 45 & 60 & 75 & \\
\hline Live weight (g) & 1190.02 & 1280.02 & 1260.04 & 1315.20 & 1325.30 & 830.11 & \pm 5.39 \\
\hline Dressed weight (g) & $1,118.50$ & $1,195.01$ & $1,132.50$ & $1,120.00$ & $1,131.50$ & 757.50 & \pm 5.14 \\
\hline Dressing (\%) & 93.99 & 93.36 & 89.98 & 85.18 & 85.40 & 91.25 & \pm 1.42 \\
\hline \multicolumn{8}{|c|}{ Carcass weight (\% live weight) } \\
\hline Head & 2.89 & 2.98 & 3.10 & 2.99 & 3.30 & 3.82 & \pm 0.24 \\
\hline Shank & 4.58 & 3.87 & 4.60 & 4.36 & 4.74 & 4.84 & \pm 0.24 \\
\hline Neck & 6.02 & 5.58 & 5.20 & 4.79 & 5.54 & 5.67 & \pm 0.27 \\
\hline Thigh & 20.05 & 21.37 & 20.12 & 19.62 & 21.60 & 19.84 & \pm 0.37 \\
\hline Wing & 8.97 & 9.18 & 10.09 & 8.34 & 9.50 & 8.78 & \pm 0.32 \\
\hline Back & 16.16 & 16.41 & 14.34 & 18.36 & 15.16 & 15.31 & \pm 0.48 \\
\hline Breast & 16.07 & 15.79 & 18.80 & 16.35 & 18.27 & 15.20 & \pm 0.48 \\
\hline \multicolumn{8}{|c|}{ Internal organs (\% live weight) } \\
\hline Kidney & 0.25 & 0.24 & 0.24 & 0.15 & 0.30 & 0.24 & \pm 0.09 \\
\hline Gizzard & 3.79 & 3.18 & 3.99 & 3.33 & 4.71 & 3.96 & \pm 0.30 \\
\hline Liver & 2.73 & 2.76 & 2.61 & 1.79 & 2.71 & 2.60 & \pm 0.25 \\
\hline Heart & 0.68 & 0.57 & 0.59 & 0.69 & 0.60 & 0.68 & \pm 0.10 \\
\hline Proventricullus & 0.60 & 0.58 & 0.58 & 0.43 & 0.59 & 0.65 & \pm 0.11 \\
\hline \multicolumn{8}{|l|}{ Length of } \\
\hline intestine $(\mathrm{cm})$ & 225.50 & 233.50 & 218.50 & 224.00 & 234.50 & 186.50 & \pm 2.43 \\
\hline
\end{tabular}

Means are values of three birds

SEM - Standard Error of Mean 
Table 4: Economics of feeding processed HEBM to finisher broilers

\begin{tabular}{lccccccc}
\hline \multicolumn{7}{c}{ Levels of HEBM (\%) } \\
Parameters & 0 & 15 & 30 & 45 & 60 & 75 & SEM \\
\hline Cost per kg of feed (N) & $84.12^{\mathrm{a}}$ & $83.12^{\mathrm{a}}$ & $81.88^{\mathrm{a}}$ & $80.48^{\mathrm{b}}$ & $78.55^{\mathrm{c}}$ & $76.42^{\mathrm{d}}$ & \pm 0.66 \\
$\begin{array}{l}\text { Cost of feed consumed } \\
\text { (N) }\end{array}$ & $\begin{array}{c}200.21 \\
\mathrm{a}\end{array}$ & $182.86^{\mathrm{a}}$ & $188.88^{\mathrm{a}}$ & $\begin{array}{l}172.51 \\
\mathrm{ab}\end{array}$ & $\underset{\mathrm{ab}}{173.85}$ & $159.20^{\mathrm{b}}$ & \pm 8.44 \\
$\begin{array}{l}\text { Cost/kg of weight gain } \\
(\mathrm{N})\end{array}$ & $\begin{array}{c}210.53 \\
\mathrm{a}\end{array}$ & $191.32^{\mathrm{b}}$ & $182.43^{\mathrm{b}}$ & $\underset{\mathrm{bc}}{177.11}$ & $\underset{\substack{179.22 \\
\mathrm{bc}}}{217.14^{\mathrm{a}}}$ & \pm 7.87 \\
\hline
\end{tabular}

Means with different superscripts within the same row are significantly different $(P<0.05)$

SEM- Standard error of means

\section{CONCLUSION}

From the results, it was concluded that up to 60 $\%$ of the soybean meal could be replaced by processed horse eye bean meal for optimum growth performance, good carcass characteristics and better economic returns.

\section{REFERENCES}

Adeyemo, G. O. and O. G. Longe., 2007. Effects of graded levels of cotton seed cake on performance, haematological and carcass characteristics of boilers fed from day old to 8 weeks of age. African Journal of Biotechnology, 6 (8): 1064-1071.

http://www.academicjournal.org./AJB

Akinmutimi, A. H. and C. C. Onwukwe., 2002. Effect of processing on metabolisability of energy and protein content of sword bean (Canavalia gladiata) using muscovry duck (Carina muschata). Tropical Journal of Animal Sci., 5:51-56.

Akinmutimi and Okwu., 2006. Effect of quantitative substitution of cooked Mucuna utilis seed meal for soybean meal in broiler finisher diet. International Journal of Poultry Science, (5): 477-275.

Ani A. O., 2008. The feeding value of processed velvet beans (Mucuna pruriens) for pullet chicks. Journal of Tropical Agriculture, Food, Environment and Extension, (7) 2: 149-155. URL:http://wwwagrosciencejournal.com/

Bamigbose, A. M., W.A. Morenikeji, O. Olayemi, A. O. Osafowora, and O. T. Ojo., 2002. Performance of breeder rabbits fed supplement Tridax procumbens diets. Proceedings of $7^{\text {th }}$ Annual Conference of Animal Science Association of Nigerian. September, $16^{\text {th }}-17^{\text {th }}: 69-70$.
Carew , L. B., D. Hardy, J.Weis, F. Alster, S. A. Mischler, A. Gernat and E. I. Zakrzewska., 2003. Heating raw velvet beans (Mucuna pruriens) reverse some anti-nutritional effects on organs histology in growing chickens. Tropical and Subtropical Agrosystems, 1: $267-275$. http://redalyl.uaemex.mx/srl/inicio/artpdfRed.jsp

Effiong, O. O., 2010. Improving the nutritional value of horse eye bean (Mucuna urens) through multiprocessing techniques for poultry feeding. A Ph.D Thesis carried out in the Department of Animal Science, University of Calabar, Nigeria.

Duncan, D. B., 1995. Multiple range and multiple FTest. Biometrics 11: $1-42$.

Emenalom, O. O. and A. B. I. Udebibie., 2005. Evaluation of different heat processing methods on the nutritive value of Mucuna pruriens (Velvet bean) seed meals for boilers. International Journal of Poultry Science, 4(8):543-548. www.pjbs.org/ijps/4(8).htm

Emenalom, O. O., M. C. Chima, E. B. Etuk, and B. O. Esonu., 2007. Comparative evaluation of processed velvet bean (Mucuna pruriens), soy bean and groundnut meals on the performance and internal organ characteristics of broilers. Proceedings of the $32^{\text {nd }}$ Annual Conference of the Nigerian society for Animal Production, 32: 220-222: ISBN1596- 5570

Emmenalom, O. O. Esonu, B. O. Etuk, E. B. \& Anaba, C., 2009. Effect of Mucuna pruriens (Velvet bean) leaf meal on performance and blood composition of finisher broiler chickens. Nigerian Journal of Animal Production, 36:1, 52-60.

Emiola, I. A, and A. D. Ologhobo., 2006. Nutritional assessment of raw and differently processed underutilized legume seed in broiler diet. 
Journal of Animal and Veterinary Advance 5 (2): $96-101$

docsdrive.com/pdfs/medwelljournals/java/2006/ $96-101$

Fanimo, A. O. A. J. Adebajo, O. O. Oduguwa, and W. O. Biobaku., 2007. Feeding value of cashew nut for broiler chickens. Nigerian Journal of Animal Production. 34 (1): 83 - 93.ISSN: 0331-2064

lyayi, E. A., V. O. Taiwo, and A. O. Fagbohun., 2005. Performance, carcass characteristics, haematological and histo pathological studies of broilers fed mucuna (Mucuna utilis) bean meal based diets. Israel Journal of Veterinary Medicine 60, (2): 51- 57.

Madubuike F. N. and V. N. Obidimma, 2009. Brewers' dried grain as energy source on external and internal egg qualities of laying hens. Proceedings of the $34^{\text {th }}$ Annual Conference of the Nigerian Society of Animal Production, 34: 362 - 365. ISBN: 1596-5590

Nyirenda, D., Musukwa, M., and L. O. Johson., 2003. The effect of different processing methods of velvet beans (Mucuna pruriens) on L-dopa content, proximate composition and broiler chicken performance. Tropical and Subtropical Agroecosystem, 1 (2-3): 253-260.

http://redalyl.uaemex.mx/srl/inicio/artpdfRed.jsp
Obi, I. U., 1990. Statistical methods of detecting differences between treatment means. $2^{\text {nd }}$ edition. Snaap press, Enugu, Nigeria.

Ogunfowora, O., 1984. Structure, cost and rations in feed management training Workshop, dept of Agric Economics, University of Ibadan, Nigeria, April 10 May 02.

Oluyemi, J. A. and F. A. Roberts., 2000. Poultry production in warm wet climate. $2^{\text {nd }}$ Revised edition. Spectrum Book Ltd. Ibadan, 93 - 96. ISBN: 978-029-097-4S

Osaniyi C. B. and O. U. Eka., 1978. Studies on chemical composition and nutritive value of horse eye bean (Mucuna urens). West African Journal of Biology and Applied Chemistry, 32:228-229.

Tuleun, C. D. and J. P. Patrick., 2007. Effect of duration of cooking Mucuna utilis seed on the proximate analysis, level of anti-nutritional factors and performance of broiler chickens. Nigerian Journal of Animal Production, 34 (1): 45 - 53. ISSN: 0331 - 2064

Umoren, U. E., O. O. Effiong, and I. A. Akpan., 2007. Nutritional evaluation of horse eye bean (Mucuna urens): Effect of processing on the chemical composition. Journal of Food, Agriculture and Environment, 3 (2): 128-131. ISSN: 1459 - 0255 